\title{
GROUPS OF METEORITE-PRODUCING METEOROIDS AND METEORITES IN ASTEROIDAL ORBITS AND THEIR SOURCES
}

\author{
Yu. M. Gorbanev ${ }^{1}$, N. A. Konovalova ${ }^{2}$, N. Kh. Davruqov ${ }^{3}$ \\ ${ }^{1}$ Astronomical Observatory of Odessa National University, Ukraine, skydust@ ukr.net \\ ${ }^{2}$ Institute of Astrophysics of the Academy of Sciences of the Republic of Tajikistan, \\ nakonovalova@mail.ru \\ ${ }^{3}$ Institute of Astrophysics of the Academy of Sciences of the Republic of Tajikistan, \\ naqqosh89@mail.ru
}

ABSTRACT. This paper presents the results of the analysis of possible existence of nine near-Earth meteorite-producing groups in asteroidal orbits, consisting of sporadic fireballs from the IAU MDC 2007 database, sporadic meteors from the SonotaCo database, meteorites - namely, L5, L6 and H4-H6 ordinary chondrites and an ureilite, for which atmospheric and orbital parameters are known from instrumental observations - and their plausible parent bodies, that is, near-Earth asteroids (NEAs). Orbits of the selected members of meteoriteproducing groups were classified as asteroidal according to the Tisserand parameter $\mathrm{T}_{\mathrm{J}}>3.1$.

In order to test the link between meteorite-producing groups in asteroidal orbits and their plausible parent bodies, we carried out an investigation into the possible existence of some known NEAs that move in similar orbits. Based on the orbital similarity, determined using the Drummond $\left(\mathrm{D}_{\mathrm{D}}\right)$ and Southworth \& Hawkins $\left(\mathrm{D}_{\mathrm{SH}}\right)$ orbital similarity criteria, some associations between the identified NEAs, known meteorites in asteroidal orbits and small, as well as meteorite-dropping, meteoroids have been suggested. As a result, several meteorite-dropping sporadic fireballs and small meteors, whose orbits are currently similar to the orbits of known meteorites, have been detected and reckoned as possible members of the groups in asteroidal orbits; their plausible source regions have also been considered.

Keywords: meteorite-producing group - meteor fireball - meteorite - ordinary chondrite - asteroid Earth-crossing orbit.

АНОТАЦІЯ. У статті представлені результати аналізу існування в навколоземному просторі дев'яти метеоритоутворюючих груп на астероїдних орбітах, що включають спорадичні боліди з бази метеорних даних IAU MDC 2007, спорадичні метеори з бази даних SonotaCo і метеорити - звичайні хондрити типів L5, L6, H4-H6 i Ureilite, з відомими по інструментальним спостереженням атмосферними і орбітальними даними, та їх можливі батьківські тіла - навколоземні астероїди. Належність орбіт відібраних членів груп до астероїдного типу визначалася за значенням параметра Тіссерана $\mathrm{T}_{\mathrm{J}}>3.1$.
Динамічний зв'язок членів виявлених метеоритоутворюючих груп з астероїдними орбітами і їх батьківських тіл NEAs перевірялася з використанням

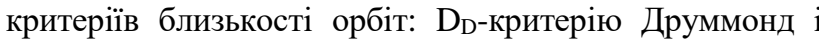
$\mathrm{D}_{\mathrm{SH}}$-критерію Саутворта і Хокінса.

В результаті кілька спорадичних метеоритоутворюючих болідів і малих метеорів, орбіти яких в даний час аналогічні астероїдним орбітах 9-ти відомих метеоритів, були знайдені в якості можливих членів метеоритоутворюючих груп, і були розглянуті їх можливі батьківські тіла - навколоземні астероїди. На підставі орбітальної подібності були виявлені асоціації між відібраними навколоземними астероїдами і 9-ма метеоритоутворюючими групами на астероїдних орбітах, що включають відомі метеорити, спорадичні боліди і малі метеори.

\section{Introduction}

The notion that meteoroid streams could originate from asteroids was suggested by Hoffmeister [1] and Fesenkov [2]. Halliday et al. [3], having analysed the fireball data from the Meteorite Observation and Recovery Project (MORP) and the Prairie Network, inferred the asteroidal origin of some fireball streams. The authors suggested existing of four possible meteorite-producing groups, among which group 1 included the Innisfree meteorite. Shestaka [4] examined a swarm of meteoriteproducing bodies, which produced the Innisfree and Ridgedale fireballs, and found out that the investigated swarm was also related to nine small meteoric swarms, several asteroids and 12 fireballs. Greenberg \& Chapman [5] reckoned meteorites might be pieces of large main-belt asteroids, derived primarily by cratering collisions rather than disruptive fragmentation of the parental body. Jopek \& Williams [6] considered the possibility that a meteoroid stream of asteroidal origin could have formed through the ejection of fragments from an asteroid due to its collision with another body (an impact as the formation mechanism). In such a case, a portion of the fragmented parent body in the form of small particles and bigger fragments, such as cobbles and pebbles, survives as debris 
in its orbit. The authors have suggested that a collision will only produce a meteoroid stream if it involves relatively large bodies, with the asteroid-impactor being of several tens of metres in diameter. The fragments of asteroid Vesta expelled in the collision with the impactor and subsequently found on Earth as meteorites - vestoids, can serve as an example of the formation of meteorites associated with impact events [7].

Spurny et al. [8] supposed the existence of a meteor stream, which might be produced by tidal disruption of a heterogeneous, rubble-pile asteroid. The evidences of high macroporosities in the interiors of some asteroids, for instance, (253) Mathilde, (1620) Geographos and (216) Kleopatra, as well as close-up images of the surface of asteroid (25143) Itokawa [9], suggest that a considerable portion of asteroids may have surface cracks (or fractures) and a rubble pile structure. Such aggregates are only held together by a relatively weak gravity and may eventually disrupt.

The fact that asteroids can indeed eject dust in such a manner (the so-called "dusty asteroids") was proved by the LINEAR (the Lincoln Near-Earth Asteroid Research project) image of comet-like asteroid P/2010 A2 with a dust tail, formed in a collision between two asteroids that had occurred in February or March 2009 [10]. Williams [11] claimed that meteoroid streams, formed through the dust ejection from an asteroidal body, would contain far less mass and be far more diffuse than those of cometary origin. In that case, the spatial density of a meteoroid stream of asteroidal origin should be lower while its meteor activity should differ from the activity of major meteor streams of cometary origin.

As the problem of asteroid impact hazard to Earth's biosphere has gained increasing attention in recent years, the international project "Asteroid \& Comet Hazard" was launched. This project involves systematic monitoring of the sky, aimed primarily at detecting near-Earth asteroids, whose orbits are similar to Earth-crossing orbits of meteoroid streams, especially short-period ones, which are close to the ecliptic and may pose an impact hazard to Earth.

\section{Methods for detecting groups of meteorites and fireballs in asteroidal orbits using meteor databases}

Annual activity of 2,373 bright shower and sporadic fireballs, observed from across Canada and documented in the Millman Fireball Archive, was studied in [12]. From the resulting solar-longitude distribution of the cumulative number of fireballs, representing an annual fireball activity profile, the peaks in the activity of fireballs from known meteor showers were identified. The peaks in the activity profile of fireballs from four meteorite-producing groups, which could be related to meteor streams of asteroidal origin, were identified as well. In the paper [13], the authors analysed data on the time of observation of superfireballs and meteorite falls in Spain, based on the reports in newspapers collected for the period covering the last 150 years. The analysis revealed statistically significant peaks corresponding to stronger fireball activity for some periods of the year, which was not associated with known meteor streams.

The study [14] yielded histograms of the annual activity of sporadic bright fireballs, meteors and meteorites, which were constructed on the basis of data adopted from two meteor databases [15, 16]. Six major (Maj) and two minor (Min) peaks in the activity of the investigated bodies, which were not connected with the dates of peak activity of known meteor showers, were identified from the plotted histograms.

All data on the detected periods of the observed activity of sporadic fireballs, meteors and meteorites laid the groundwork for addressing the issue of clustering the data on near-Earth sporadic meteorite-producing meteoroids. Data on atmospheric paths, radiants and heliocentric orbits for 24 known meteorites, instrumentally observed in different years, have been published in scientific journals to date. Of these 24 Earth-crossing orbits for known meteorites, four orbits of $\mathrm{CI}$ and $\mathrm{CM}$ carbonaceous chondrites and six orbits of L3.5 and H5 ordinary chondrites are Jupiter-family comet-like orbits, while 14 orbits of L5, L6, H4-H6 chondrites and an ureilite are recognised as asteroidal.

A search for fireballs and meteors with orbits similar to Earth-crossing asteroidal orbits of 14 known meteorites was carried out in two meteor databases. We used the following method for detecting groups of meteorites and fireballs in asteroidal orbits: the data on a known meteorite - in particular, its orbital elements, radiant coordinates and date of observation - were employed as a reference for the search of members of the relevant meteorite-producing meteoroid group. The selection of meteorite-producing meteoroids as members of a specific group was performed by comparing respective data of the meteorite and potential members of the group; in so doing, meteoroids in orbits proven to be similar by the specified orbital similarity criteria were only selected. The search among 14 known meteorites in Earth-crossing asteroidal orbits yielded groups of meteorite-producing meteoroids linked to nine of the known meteorites, namely Innisfree, Novato, Villalbeto de la Peña, Lost City, Križevci, St. Robert, Grimsby and Almahata Sitta.

\section{Groups of meteorite-producing meteoroids in asteroidal orbits and their plausible parent bodies}

In the present study, we investigated the possibility of the existence of near-Earth meteorite-producing groups in asteroidal orbits, consisting of sporadic meteoroids, meteorite-dropping fireballs and instrumentally observed meteorites. The selection of members of the groups was carried out as follows: sporadic meteorite-dropping fireballs, which could survive the flight through Earth's atmosphere with a non-zero terminal mass, were selected from the IAU MDC 2007 database [15], and sporadic meteors - from the SonotaCo database [16]. As a groupmembership criterion to be met for the selection of meteorite-producing sporadic fireballs, meteoroids and meteorites, we used the similarity of orbits of a group's members to the orbit of a known, instrumentally observed meteorite that fell within the time span of the observed occurrence of fireballs from the group and that was taken as a reference for the search of potential group members.

The similarity between the orbits was established applying two known criteria, used as a quantitative measure of the distance between the orbits, namely the 
Southworth-Hawkins $\mathrm{D}_{\mathrm{SH}}$ criterion [17] and the Drummond $\mathrm{D}_{\mathrm{D}}$ criterion [18]. The following limit values of the orbital similarity criteria were used for selecting into the groups: $\mathrm{D}_{\mathrm{D}}<=0.15$ and $\mathrm{D}_{\mathrm{SH}}<=0.3$. Orbits of the selected fireballs, meteors and instrumentally observed meteorites were recognised as asteroidal according to the Tisserand parameter $\mathrm{TJ}>3.1$.

The search, based on the orbital similarity, duration of observations (1.5-2 months) and radiant positions $\left(\Delta \alpha_{R}<\right.$ $\left.15^{\circ}\right),\left(\Delta \delta_{\mathrm{R}}<30^{\circ}\right)$ of meteorite-producing meteoroids and meteors, selected from the meteor databases, resulted in the detection of associated groups of meteorite-producing meteoroids for 9 of 14 meteorites of asteroidal origin with observationally known atmospheric and orbital parameters. Details about nine detected meteoriteproducing groups are listed in the Table below, providing the following data for each of the groups: a meteorite's name; year, month and date of observations; radiant coordinates - the right ascension $\left(\alpha_{R}\right)$ and declination $\left(\delta_{R}\right)$; the entry (pre-atmospheric) velocity $\left(\mathrm{V}_{\infty}\right)$; orbital elements, including the perihelion (q), semi-major axis (a), orbital eccentricity (e) and inclination (i), the argument of perihelion $(\omega)$, the longitude of the ascending node $\Omega$; the orbital similarity criteria $\mathrm{D}_{\mathrm{D}}$ and $\mathrm{D}_{\mathrm{SH}}$, and also parameters of the respective mean orbit, for which the number of meteorite-producing meteoroids that are members of the group is included in round brackets.
Orbits of nine meteorite-producing groups are illustrated in Figures 1; in particular, each figure depicts a meteorite's instrumentally determined orbit, the mean orbit of the respective group and also orbits of the group members, that is, meteorite-dropping fireballs in asteroidal orbits.

\section{Conclusions}

In the present study, the search among objects, selected from the IAU MDC 2007 and the SonataCo Network databases by the orbital similarity criteria, duration of the observed activity and radiant co-ordinates, has yielded nine meteorite-producing groups of sporadic fireballs and meteors in asteroidal orbits, which include nine known, instrumentally observed meteorites - namely, L5, L6, H4H6 ordinary chondrites and an ureilite. The analysis of the search in the meteor databases for plausible meteoriteproducing groups for four meteorites, namely the Peekskill, Morávka, Bunburra Rockhole and Buzzard Coulee meteorites, with instrumentally determined atmospheric paths and orbital parameters has not shown any results with regard to meteorite-producing groups found for these meteorites in the available meteor and fireball databases.

Table 1: The detected groups of meteorites and meteorite-dropping fireballs with similar orbits (at epoch 2000.0).

\begin{tabular}{|c|c|c|c|c|c|c|c|c|c|c|c|c|c|c|}
\hline Name & Year & M & D & $\alpha_{R}$ & $\delta_{R}$ & $V_{\infty}$ & $\mathrm{q}$ & a & e & $\mathrm{i}$ & $\omega$ & $\Omega$ & $D_{D}$ & $\mathrm{D}_{\text {sH }}$ \\
\hline \multicolumn{15}{|c|}{ The Innisfree (L5) meteorite group } \\
\hline Mean (14) & - & 02 & 09 & 41.0 & 54.0 & 13.7 & 0.990 & 1.868 & 0.470 & 8.0 & 185.0 & 319.0 & 0.00 & 0.00 \\
\hline Innisfree & 1977 & 02 & 06 & 6.7 & 66.2 & 14.5 & 0.990 & 1.868 & 0.470 & 12.0 & 178.0 & 317.0 & 0.03 & 0.10 \\
\hline \multicolumn{15}{|c|}{ The Jesenice (L6) meteorite group } \\
\hline Mean (11) & - & 04 & 01 & 139.5 & 51.8 & 13.9 & 0.977 & 1.838 & 0.456 & 8.4 & 192.7 & 21.8 & 0.00 & 0.00 \\
\hline Jesenice & 2009 & 04 & 09 & 159.9 & 58.7 & 13.8 & 0.996 & 1.750 & 0.431 & 9.6 & 190.5 & 19.2 & 0.03 & 0.05 \\
\hline \multicolumn{15}{|c|}{ The Novato meteorite group } \\
\hline Mean (12) & - & 10 & 01 & 289.8 & -26.1 & 13.8 & 0.982 & 2.132 & 0.534 & 2.7 & 314.6 & 21.4 & 0.00 & 0.00 \\
\hline Novato & 2012 & 10 & 18 & 268.1 & -48.9 & 13.7 & 0.988 & 2.090 & 0.526 & 5.5 & 347.4 & 24.9 & 0.11 & 0.33 \\
\hline \multicolumn{15}{|c|}{ The Villalbeto de la Peña (L6) meteorite group } \\
\hline Mean (7) & - & 12 & 27 & 321.1 & 4.2 & 15.9 & 0.921 & 2.379 & 0.607 & 5.3 & 142.3 & 278.1 & 0.00 & 0.00 \\
\hline Villalbeto & 2004 & 01 & 04 & 311.4 & -18.0 & 16.9 & 0.860 & 2.300 & 0.630 & 0.0 & 132.3 & 283.7 & 0.05 & 0.12 \\
\hline \multicolumn{15}{|c|}{ The Lost City (H5) meteorite group } \\
\hline Mean (10) & - & 01 & 01 & 249.9 & 26.0 & 14.1 & 0.956 & 1.802 & 0.464 & 7.1 & 165.2 & 285.8 & 0.00 & 0.00 \\
\hline Lost City & 1970 & 01 & 04 & 315.0 & 39.1 & 14.2 & 0.967 & 1.660 & 0.417 & 12.0 & 161.0 & 283.8 & 0.06 & 0.11 \\
\hline \multicolumn{15}{|c|}{ The Križevci (H6) meteorite group } \\
\hline Mean (19) & - & 02 & 21 & 137.0 & 17.8 & 18.9 & 0.783 & 2.075 & 0.614 & 3.4 & 242.2 & 328.6 & 0.00 & 0.00 \\
\hline Križevci & 2011 & 02 & 04 & 131.2 & 19.5 & 18.2 & 0.740 & 1.544 & 0.521 & 0.6 & 254.4 & 315.6 & 0.09 & 0.11 \\
\hline \multicolumn{15}{|c|}{ The St. Robert meteorite group } \\
\hline Mean (16) & - & 06 & 02 & 187.9 & 12.0 & 13.3 & 0.994 & 2.085 & 0.517 & 4.2 & 191.5 & 71.6 & 0.00 & 0.00 \\
\hline St. Robert & 1994 & 06 & 15 & 176.0 & 6.0 & 13.0 & 1.016 & 1.900 & 0.480 & 0.7 & 179.0 & 83.7 & 0.04 & 0.08 \\
\hline \multicolumn{15}{|c|}{ The Grimsby (H4-6) meteorite group } \\
\hline Mean (8) & - & 09 & 17 & 251.9 & 49.8 & 19.4 & 0.997 & 2.290 & 0.554 & 24.4 & 171.5 & 175.7 & 0.00 & 0.00 \\
\hline Grimsby & 2009 & 09 & 26 & 242.6 & 55.0 & 20.9 & 0.982 & 2.040 & 0.518 & 28.1 & 159.9 & 182.9 & 0.05 & 0.10 \\
\hline \multicolumn{15}{|c|}{ The Almahata Sitta (Ureilite) meteorite group } \\
\hline Mean (7) & - & 09 & 23 & 339.5 & 13.9 & 14.4 & 0.888 & 1.413 & 0.312 & 6.1 & 235.4 & 187.4 & 0.00 & 0.00 \\
\hline Ahs & 2008 & 10 & 07 & 348.1 & 7.6 & 12.4 & 0.900 & 1.308 & 0.312 & 2.5 & 234.4 & 194.1 & 0.02 & 0.07 \\
\hline
\end{tabular}



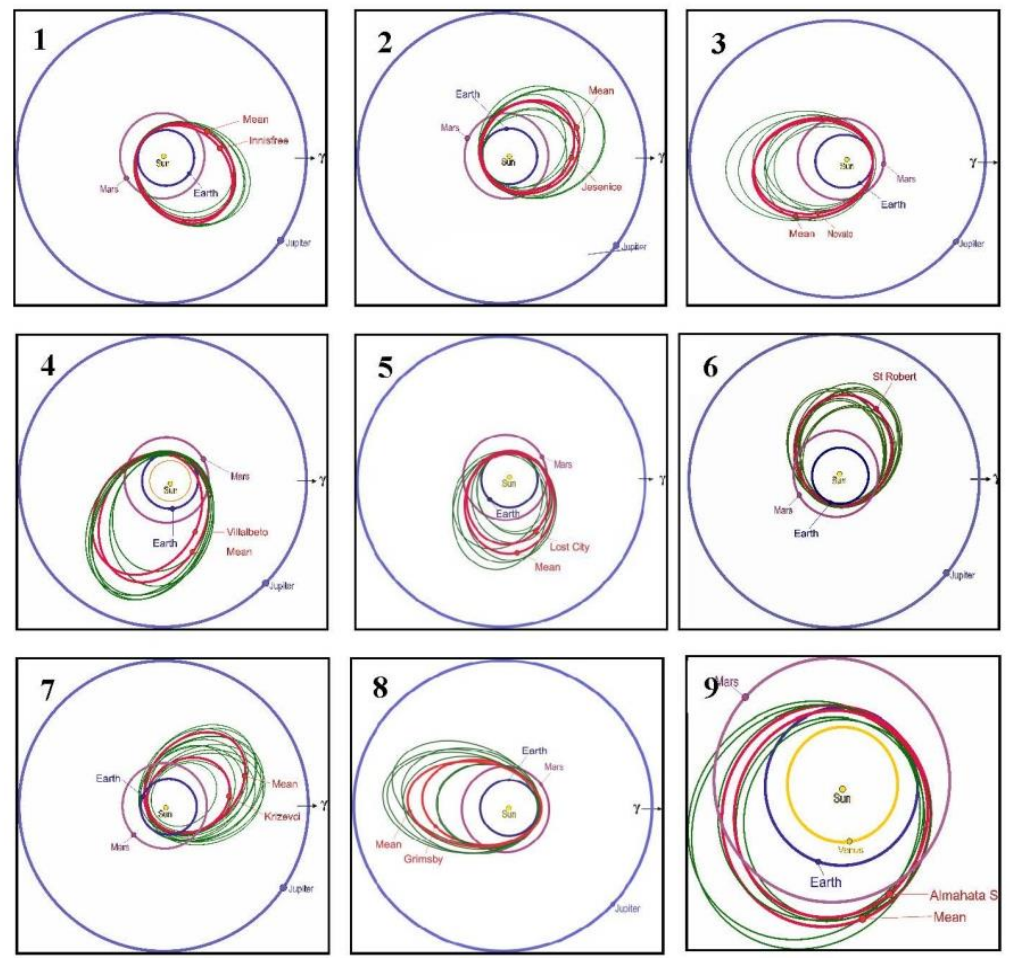

Figures 1: Nine groups of meteorites and meteorite-dropping fireballs in asteroidal Earth-crossing orbits.

According to one of possible scenarios, the similarity of orbits of the group members, that is, members of a genetically associated group, could have formed through the disruptive fragmentation of the parent body (NEA) and thus become a group of genetically related members. Porubčan et al. [19] pointed out that they only included as real genetically related pairs of meteoroids and plausible parent NEAs those for which the orbital evolution was proven to be similar over 5,000 years. In an alternative scenario, such a relationship between meteoroids within a certain group could have formed randomly. Both scenarios do not rule out possible existence of meteoriteproducing meteoroids related to the investigated groups.

The feasibility of identifying a plausible parent body related to a specific group and determining the age of the group of genetically associated meteoroids is crucial for establishing relationships between groups of meteoriteproducing meteoroids and their parents, that is, comets or asteroids, and also for studying mechanisms of formation of the investigated meteorite groups.

Within the framework of the project addressing the problem of asteroid impact hazard to the environment and Earth's biosphere in particular, it is essential to systematically monitor the sky at the radiant points specified for meteorite-producing groups during periods of their activity. Ultimately, it is extremely important to detect potentially hazardous meteorite-producing meteoroids in near-Earth space well before they enter Earth's atmosphere.

\section{References}

1. Hoffmeister C.: 1937, Astronomische Nachrichten, 262, Is. 3, 45.

2. Fesenkov V.G.: 1958, Astron. zhurnal. 35, № 3, 327.

3. Halliday I. Blackwell A.T., Griffin A.A.: 1990, Meteoritics, 25, 93.

4. Shestaka I.S.: 1994, Astronom. Vestnik, 28, No. 6, 94.

5. Greenberg R., Chapman C.R.: 1984, Icarus, 57, Is. 2, 267.

6. Jopek T.J.; Williams I.P.: 2013, MNRAS, 430, Is.3, 2377.

7. Pieters C. M., Binzel R. P., Bogard D., Hiroi T., Mittlefehldt D. W., Nyquist L., Rivkin A., Takeda H.: 2006, IAUS, 229, 273.

8. Spurny P., Olberst J., Heinlein D.: 2003, Nature, 423, 151.

9. Miyamoto H., Nakamura A. M., Nakamura R., Sasaki S. and Uesugi K.: 2006, Science, 312, 1330.

10. Jewitt D.: 2012, AJ, 143 (3), 66J, 14.

11. Williams I. P. \& Wu Z. 1993, MNRAS, 262, 231.

12. Beech M.: 2006, Journal of WGN IMO, 34, 104.

13. Zamora S., Ocana F., Sanchez de Miguell A. and Mole M.: 2015, in Proc. of the International Meteor Conference, Mistelbach, Austria, 27-30 August 2015 /Eds.: Rault, J.-L.; Roggemans, P., International Meteor Organization, 187.

14. Konovalova N.A., Gorbanev Yu.M., Davruqov N.Kh.: 2018, Odessa Astron. Publ., 31, 174.

15. http://www.astro.sk/ ne/IAUMDC/Ph2007/database.html

16. SonotaCo database. http://sonotaco.jp/doc/SNM/ index.html

17. Southworth R.B., Hawkins G.S.: 1963, Smiths. Contrib. Astrophys., 7, 261.

18. Drummond J.D.: 1981, Icarus, 45, 545.

19. Porubčan V., Kornos L., Williams I.P.: 2004, Earth, Moon, Planets, 95, 697. 